\section{Group therapy for morbid jealousy}

Grupo psicoterapêutico para ciúme excessivo

Daniel Carr Ribeiro Gulassa ${ }^{1}$, Andrea Lorena da Costa $^{2}$, Eglacy Cristina Sophia ${ }^{3}$, Cintia Cristina Sanches ${ }^{4}$, Talita Vendrame ${ }^{4}$, Monica L. Zilberman ${ }^{5}$

${ }^{1}$ Psicólogo, Ambulatório Integrado dos Múltiplos Transtornos do Impulso (Pró-AMITI), Hospital das Clínicas, Faculdade de Medicina, Universidade de São Paulo (USP), São Paulo, SP. ${ }^{2}$ Psicóloga, Pró-AMITI. Mestre em Ciências, USP. ${ }^{3}$ Psicóloga, Pró-AMITI. Mestre e Doutoranda em Ciências, USP. ${ }^{4}$ Psicóloga, Pró-AMITI. ${ }^{5}$ Médica psiquiatra. Professora, Programa de Pós-Graduação, Departamento de Psiquiatria, USP. Pesquisadora, Laboratório de Psicofarmacologia, Instituto de Psiquiatria, Hospital das Clínicas, Faculdade de Medicina, USP.

Dear Editor,

Romantic or normal jealousy is defined as a perceived threat of loss of an important relationship. Morbid jealousy, in turn, is characterized by extreme possessiveness and aggressiveness, causing suffering to both partners. ${ }^{1}$ Morbid or pathological jealousy can be classified as delusional (psychotic) or obsessive (excessive). Delusional jealousy is egosyntonic: the person is confident that his/her partner is being unfaithful, even when reality implies the opposite. Conversely, excessive jealousy is egodystonic, i.e., the person is frequently able to distinguish between beliefs and reality and to examine his/her own thoughts. ${ }^{2}$

Research on morbid jealousy is scarce. Therefore, we decided to develop a study and recruit individuals who realized that jealousy was bringing suffering upon him/her and/ or their partner. A psychotherapy group treatment was initiated, comprising 18 weekly sessions based on psychodramatic analysis. ${ }^{3}$

Eight adult female subjects provided written consent and joined the program. Mean age was 35.4 years (standard deviation, $\mathrm{SD}=11.9$ ). Three of the participants were living with their partners, four were dating, and one was not involved in a romantic relationship at the moment.

Psychiatric morbidity was evaluated using the Mini International Neuropsychiatric Interview (MINI). ${ }^{4}$ Major depression was found in four subjects. Hypomania, panic disorder, agoraphobia, social phobia, obsessive-compulsive disorder, alcohol abuse and/or dependence, and generalized anxiety disorder were also diagnosed (one subject in each category). Four subjects reported previous suicide attempts; seven were taking psychiatric medications (selective serotonin reuptake inhibitors in five and risperidone in two).
Subjects answered the Questionnaire on the Affective Relationships (QAR), ${ }^{1}$ a 4 -point scale with scores ranging from 30 to 120, and the Jealousy Health Scale (JHS), a 6-point Likert-type analog scale with scores from 0 to 100. In both scales, higher scores mean increased jealousy intensity. Irritability, hostility, anger and aggressiveness were assessed using the Bond-Lader Visual Analog Scale (BLVAS), ${ }^{5}$ which presents $13100-\mathrm{mm}$ horizontal lines placed between opposite adjectives. Relationship quality was assessed by the Relationship Assessment Scale (RAS) adapted into Brazilian Portuguese. $^{4}$

Mean overall QAR score was $86.9(\mathrm{SD}=11.1)$ before treatment and $82.6(\mathrm{SD}=14.6)$ after treatment, suggesting a significant reduction in jealousy intensity (Wilcoxon matched-pairs test, $z=-1.997 ; p=0.046)$. The most significant reductions were observed in avoidance behaviors $(\mathrm{z}=$ $-2.539 ; p=0.001)$ and in the level and quality of sexual activity $(\mathrm{z}=-2.226 ; \mathrm{p}=0.026)$. JHS yielded a pre-treatment mean score of $95.0(\mathrm{SD}=10.7)$, compared to a post-treatment score of $51.3(\mathrm{SD}=26.9 ; t=-5.185 ; \mathrm{p}=0.001)$.

On BLVAS, the following items showed significant improvement, with lower levels of aggressiveness: friendly/ provocative $(63[\mathrm{SD}=29.5]$ vs. $37[\mathrm{SD}=18.5] ; \mathrm{z}=-2.1 ; \mathrm{p}=$ $0.036)$, patient/impatient ( $82[\mathrm{SD}=16.2]$ vs. 58 [SD = 18.5]; $\mathrm{z}=-2.524 ; \mathrm{p}=0.012)$ and satisfied/boring $(80[\mathrm{SD}=20.3]$ vs. $58[\mathrm{SD}=15.7] ; \mathrm{z}=-2.243 ; \mathrm{p}=0.025)$. In addition, relationship quality improved significantly after treatment (17 $[\mathrm{SD}=6.4]$ vs. 19 [SD = 6.2], $\mathrm{z}=-2.214, \mathrm{p}=0.027$ ).

Although our study yielded promising results, our analysis and the generalization of our findings is limited by the small sample size. Further research with larger samples and under controlled conditions is warranted to expand our preliminary results.

\section{References}

1. Marazziti D, Di Nasso E, Masala I, Baroni S, Abelli M, Mengali F, et al. Normal and obsessional jealousy: a study of a population of young adults. Eur Psychiatry. 2003;18:106-11.

2. Kingham M, Harvey G. Aspects of morbid jealousy. Adv Psychiatr Treat. 2004; 10:207-15

3. Lorena A, Sophia EC, Mello C, Tavares H, Zilberman M. Group therapy for pathological love. Rev Bras Psiquiatr. 2008;30(3):290-301.

4. Sophia EC, Tavares H, Berti M, Pereira AP, Lorena A, Mello C, et al. Pathological love: impulsivity, personality, and romantic relationship. CNS Spectr. 2009;14(5):268-74.

5. Bond AJ, Lader M. A method to elicit aggressive feeling and behaviors via provocation. Biol Psychol. 1986;22:69-79.

\title{
Correspondence:
}

Daniel Carr Ribeiro Gulassa, Rua Monte Alegre, 428/76, CEP 05014-000, Perdizes, São Paulo, SP, Brazil. E-mail: danielgulassa@hotmail.com No conflicts of interest declared concerning the publication of this letter.

Copyright (C) Revista de Psiquiatria do Rio Grande do Sul - APRS 